\title{
Compression behavior of reconstituted clay: A study on black clay
}

\author{
*Bhim Kumar Dahal and Jun-Jie Zheng \\ School of Civil Engineering and Mechanics, Huazhong University of Science and Technology, Wuhan, China \\ *Corresponding author:dahal_bhim@yahoo.com
}

\begin{abstract}
The soft and black clay found in the Kathmandu Valley is locally known as Kalomato which is highly compressible and weak. The Kalomato from the Khasibazaar is taken as study material. Experimental study is carried out on undisturbed, remoulded and reconstituted soil samples to determine the compression behaviour. The study revealed that the undisturbed soil sample has the highest compression index among all samples while the remolded sample has the lowest compression index. The reconstituted soil sample using cement shows that the compression index increases with the increase in cement content while decrease with the increase in curing time. When cement content increases to $15 \%$, the load required to compress the soil to the equal void ratio also increases to almost three times of the undisturbed soil and seven times of the remoulded soil. Therefore, reconstitution of soil using cement is found as effective method for improvement of compression behaviour. This study also has established graphical interrelations between the compression index, swelling index and the cement content which can be used in the study of Kalomato.
\end{abstract}

Keywords: Cement, Compression, Kalomato, Swelling

Paper Received: 31 Jan 2018

Paper Accepted: 17 March 2018

\section{INTRODUCTION}

Deformation due to load from the construction of infrastructure in soft ground is very high which may cause failure of structure. Soil in the Kathmandu Valley especially black clay locally known as Kalomato is also very soft and compressive in nature. Kalomato was formed after deposition of fine sediments into a lake, from river and streams with significant amount of organic matters. Presence of organic matter can often be traced by its color and odour during field exploration. In some drilling location outburst of gas as well as strong order was found (Handali et al. 2011; Khadka, 2011). To date, no systematic attempt has been done to map the extent of Kalomato in Kathmandu, but from the borehole data collected from different sites, it is evident that the soil is found almost in the entire Valley (Piya et al., 2004; Sakai, et al. 2008; Handali et al., 2011). However, the distribution is not even throughout the valley, based on the prevailing data, and it is seen that maximum thickness of Kalomato found is more than $20 \mathrm{~m}$ at Thapathali whereas minimum thickness is $1 \mathrm{~m}$ in Maharajganj. Similarly, the depth at which the clay layer is found also varies in different places (Handali et al., 2011). Kalomato is found almost at ground surface in some locations like Thapathali, Sanothimi and Bhaktapur but in Kalimati, Balkhu, Tahachal and Gyaneshwor it starts at $5 \mathrm{~m}$ from the ground surface. In some places like Ratna Park and Pulchowk, it occurs at $10 \mathrm{~m}$ depth. In many places it will be found even in greater depth. Therefore, developer, builders and engineers are worried about the presence of Kalomato, its thickness and depth in their sites. Because of these detrimental effects, Kalomato is gaining the interest of Geotechnical researchers.

\section{Location and Geology}

The clay sample from Khasibazaar Kathmandu, Nepal is used for the laboratory investigations. The Khasibazaar lies in the west side of the Kathmandu Valley. The study area is just inside the Kathmandu Valley ring road which confined core city area. In this context the study area has good access and huge potential of future development. The location of the study area is presented in Fig. 1.

Soil of the Kathmandu Valley is thick quaternary sediments and recent alluvium underlain by basement rock. The depth of the sediments varies up to $600 \mathrm{~m}$ (Kharel et al., 1998). Yoshida and Igarashi (1984) have found that the central part of the Kathmandu Valley is composed of three formations; they are Patan, Thimi and Gokarna formations. Later on Dongol (1987) has combined these formations in a single group as Kalimati clays. Further study has extended the Kalimati Formation including Kalimati clays and a part of the Lukundol Formation (Sakai, 2001). This formation covers almost all central part of the valley where occurrence of black clay is very common. The study area Khasibazaar also belongs to the Kalimati Formation. The Kalimati Formation is the formation which consists of black clay or silts beds with some thin layers of fine to very fine sand . This formation is more than $200 \mathrm{~m}$ thick and the sediments were deposited in the center of the lake mainly from the suspension. The presence of fine to very fine sand in between clay layers is because of turbidity flows from an adjacent delta. 


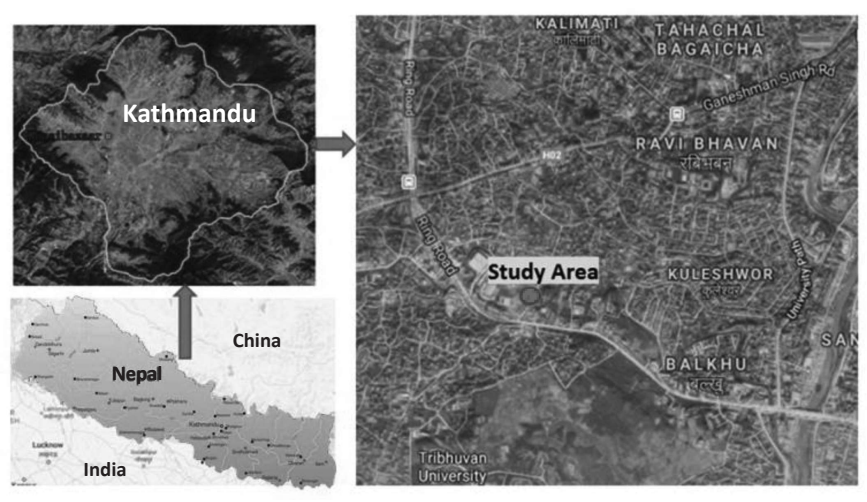

Fig. 1: Location map of the study area (source: Google map)

\section{Physical and compression behavior of Kalomato}

The study on Kalomato soils from four different sites namely Kupondole, Kritipur, Kalimati and Pulchowk were carried out which shows that the physical properties of the clay are different from place to place (Handali et al., 2011). Those studies showed that the physical properties vary with the location and depth of soil. Properties like liquid limit, specific gravity and plasticity index are found in the range of $60 \%-140 \%$, $2.25-2.6$ and $25 \%-64 \%$ respectively. Similarly, the content of organic matter in these sites ranges from 4.4 to $13.1 \%$ and the compression index of the Kalomato also has high variation i.e. from 0.49 to 1.3. The variation in the most of the properties is found as much as twice depending on the location. Similar results were found from the different study sites for physical properties of the Kalomato as shown in Table 1 (Khadka, 2011).

\section{Compression behavior of cemented clay}

There are various methods to improve the compression behavior of the soft clay. The most common method is soil modification using cement which is fast, efficient and cheap Broms (1984). The improvement in the soil characteristics is affected by various factors. These factors can be categorized into four main groups namely; (i) Type of admixture, (ii) type of soils, (iii) mixing conditions, and (iv) curing time (Terashi, 1997). Various studies found that the compression behavior of the cemented clays shows that the compression behavior is also governed by these factors. But, the compression index of

Table 1: Properties of Kalomato from different loactions (Khadka, 2011)

\begin{tabular}{lllll}
\hline Location & Depth (m) & Soil Type & LL (\%) & PL (\%) \\
\hline Balkhu & $3-15$ & OH & $54.5-112.1$ & $26.23-68.97$ \\
Bhakatapur & 3 & MH & $69.0-132.5$ & $53.28-116.01$ \\
Koteshwor & $5-40$ & OH & 58.0 & 36.0 \\
Gothatar & $10-20$ & OH & 66.2 & 32.5 \\
Kalimati & $0-5$ & $\mathrm{CH} / \mathrm{O}$ & 62.0 & 33.0 \\
Kuleshwor & $10-20$ & $\mathrm{OH}$ & 59.0 & 20.0 \\
\hline
\end{tabular}

cemented Singapore marine clay has been found to be independent of cement content, curing time, curing stress and initial water content. However, primary yield stress increases with increase in above-mentioned parameters except for initial water content (Xiao, 2009). Primary yield stress is the point at which the compression curve changes its slope (Rotta et al., 2003). Some researchers concluded that compressibility depends on the state of structure presence in soil matrix and rate of destructuration and found that after complete destructuration the clay will have unique slope as reconstituted natural soil sample (Liu et al., 2000; Bergado et al., 2006; Herpibulshuk et al., 2016). But the rate of the destructuration is different for different soil sample, so that slope of virgin compression line remains constant throughout the stress range of our interest.

There are various relationships established between compression index and physical properties namely liquid limit, plasticity index and initial void ratio. It is found that the compression index linearly varies with the initial void ratio (Nishida, 1956; Rendon-Herrero, 1980). Similarly, the compression index also has the linear relations with the liquid limit for natural and remolded soils (Skempton, 1944; Terzaghi and Peck, 1996). The recent study on different clay samples prepared by mixing montmorillonite, kaolinite, illite, and quartz at initial moisture contents equal to the liquid limit also obey the similar relationships as suggested by the previous researchers (Tiwari and Azmera, 2012). The research delineates the linear relationships for compression index and liquid limit into two groups on the basis of clay activity.

In this study, compression and swelling behaviour of Kalomato are studied in undisturbed, remoulded and reconstituted state using ordinary Portland cement. The interrelationship between cement content, compression index and swelling index is evaluated from the laboratory investigations.

\section{METHODOLOGY}

The undisturbed soil samples were taken from Khasibazaar Kathmandu, Nepal. The samples were obtained at the depth of $3 \mathrm{~m}$ from the ground surface. The soil samples were taken in steel tubes and sealed at both ends with wax to prevent from the moisture exchange. These samples were transported to the laboratory with the minimum possible disturbance. The soil was taken out from sampling tube using hydraulic sample extruder. The extruded cylindrical soil sample was trimmed using soil trimming lathe. The final dimension of the specimen was $61.8 \mathrm{~mm}$ in diameter and $20 \mathrm{~mm}$ in height which was equal to the dimension of consolidation ring. Three sets of the undisturbed samples were prepared form each sampling tubes (UD1 and UD2) and tested using incremental loading procedure as per ASTM D 2435.

Ordinary Portland cement (OPC) of Grade 42.5 was used for the reconstitution of the clay. OPC is very common additives for soil modification. It is also easily available and cheap. The chemical compositions of cement and properties of soil used in the study are presented in Table 2. 
Clay

Drying, Crushing and Sieving through $425 \mu \mathrm{m}$

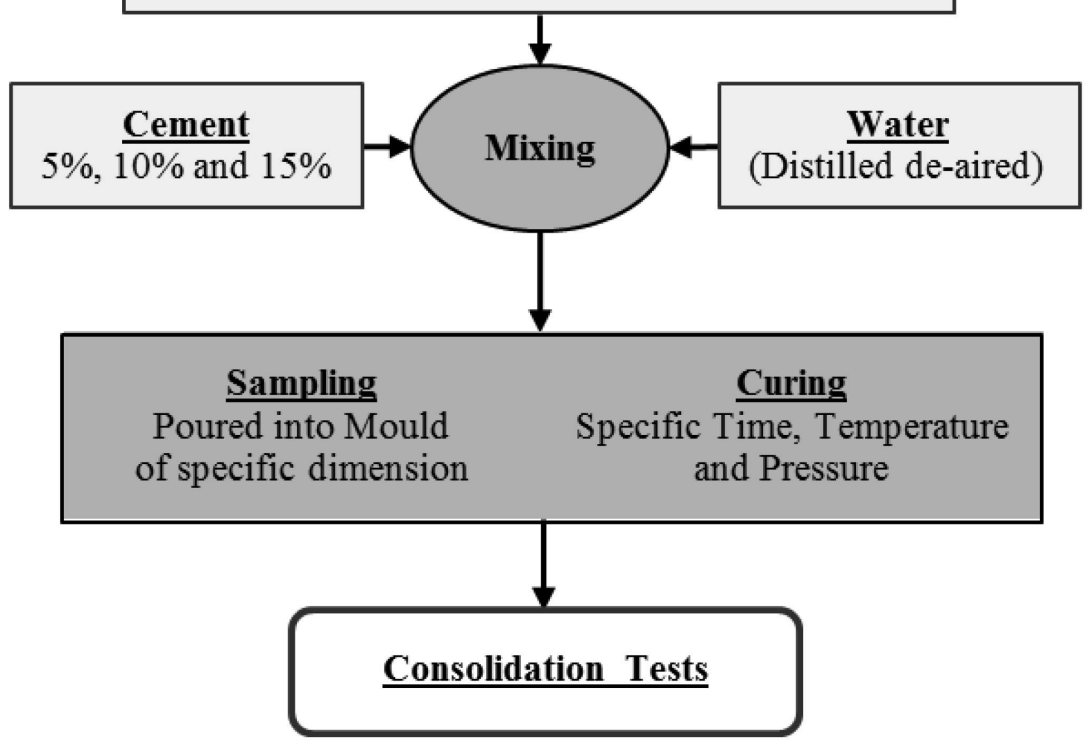

Fig. 2: Schematic diagram for laboratory investigation of reconstituted soil sample

Three sets of cemented samples were prepared and tested in the laboratory as shown in schematic diagram (Fig. 2). The Kalomato was crumbled into small pieces using the knife and left it to the room temperature for air drying. After a week of drying, the soil had negligible changes in mass and was taken as the air-dried sample. The sample was crushed using mallet hammer and sieved through a 425 ìm sieve. This clay powder was mixed thoroughly with cement and distilled de-aired water. Water content for the mix was taken as $110 \%$ (1.25 time the liquid limit) of the mass of dry soil and $100 \%$ of the mass of the cement. The mixture was mixed in the Hobart mixture for 10 mins. Then the well mixed slurry was poured in the mould of $61.8 \mathrm{~mm}$ diameter and $40 \mathrm{~mm}$ height. The mould has porous stone in top and bottom for free-drainge through out the curing period. Samples were cured for 10 days and 28 days in constant temperature water bath at $25^{\circ} \mathrm{C}$. The reconstituted soil samples were prepared using $10 \%$ and $15 \%$ of cement by dry mass of soil. All the cemented samples were cured under atmospheric pressure and tested after different curing periods.

To determine the compression characteristics of the remoulded Kalomato, the dry soil powder is mixed with the distilled de-aired water. The water content was used as $110 \%$ of the mass of dry soil. This slurry was poured in the same mould used in the preparation of specimen for cemented soil. Remoulded clay samples were cured under $10 \mathrm{kPa}$ overburden pressure.

Table 2: Characterization of the materials used in study

\begin{tabular}{lcc}
\hline \multicolumn{3}{c}{ Ordinary Portland Cement (OPC) } \\
\hline Chemical compositions & Units & Values \\
\hline Magnesia, $\mathrm{MgO}$ & $(\%, \mathrm{~m} / \mathrm{m})$ & 2.57 \\
Sulphuric Anhydride as $\mathrm{SO}_{3}$ & $(\%, \mathrm{~m} / \mathrm{m})$ & 2.82 \\
Silica, $\mathrm{SiO}_{2}$ & $(\%, \mathrm{~m} / \mathrm{m})$ & 20.26 \\
Calcium $\mathrm{Oxide}_{\mathrm{CaO}}$ & $(\%, \mathrm{~m} / \mathrm{m})$ & 60.82 \\
Iron Oxide, $\mathrm{Fe}_{2} \mathrm{O}_{3}$ & $(\%, \mathrm{~m} / \mathrm{m})$ & 3.61 \\
Aluminium $\mathrm{Oxide}, \mathrm{Al}_{2} \mathrm{O}_{3}$ & $(\%, \mathrm{~m} / \mathrm{m})$ & 6.52 \\
Sodium Oxide, $\mathrm{Na}_{2} \mathrm{O}$ & $(\%, \mathrm{~m} / \mathrm{m})$ & 0.25 \\
Potassium Oxide, $\mathrm{K}_{2} \mathrm{O}$ & $(\%, \mathrm{~m} / \mathrm{m})$ & 0.30 \\
\hline
\end{tabular}

Soil (Kalomato)

\begin{tabular}{lcc}
\hline \multicolumn{1}{c}{ Description } & Units & Values \\
\hline Depth of Sampling & $(\mathrm{m})$ & 3.00 \\
Density $(\rho)$ & $(\mathrm{gm} / \mathrm{cc})$ & 1.57 \\
Sp. Gravity (G) & & 2.53 \\
Natural water Content & $(\%)$ & 82.60 \\
Liquid Limit (LL) & $(\%)$ & 87.83 \\
Plastic Limit (PL) & $(\%)$ & 65.69 \\
\hline \multicolumn{2}{c}{ Number of Undisturbed sample tubes collected } \\
\multicolumn{2}{c}{ from field: 3 } \\
Location: Khasibazaar, Kathmandu, Nepal
\end{tabular}




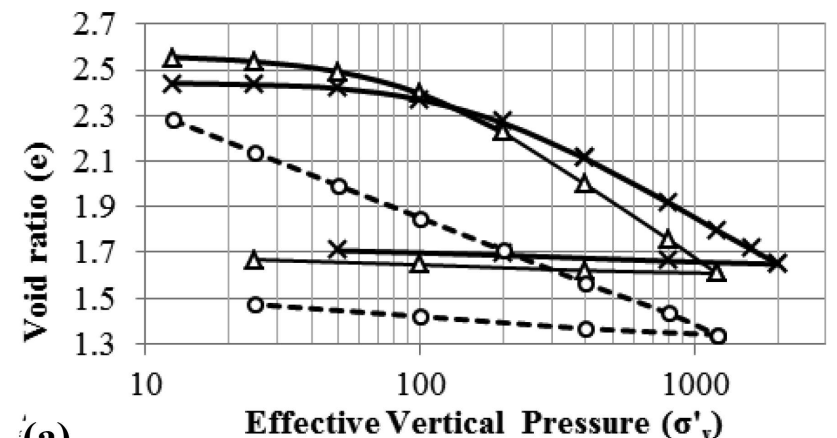

(a)

Effective Vertical Pressure $\left(\sigma^{\prime}{ }_{v}\right)$
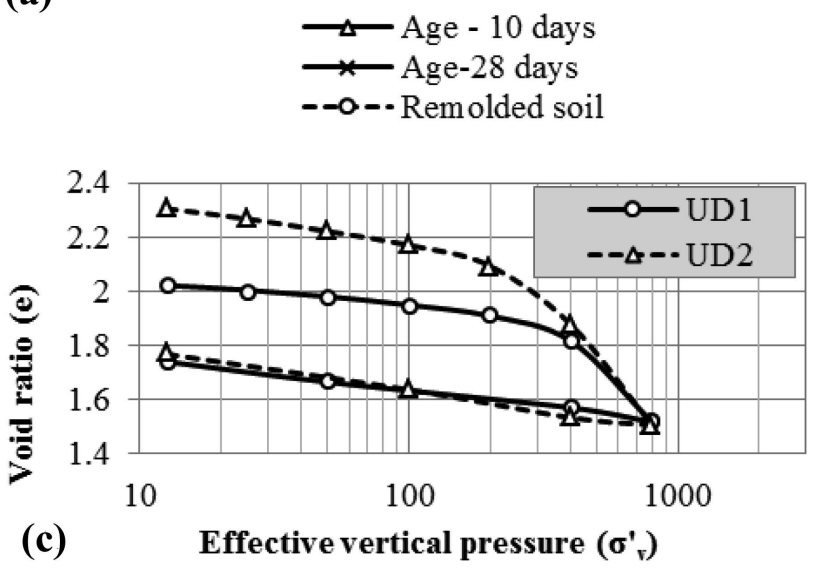

Fig. 3: Compression and swelling behaviour of Kalomato

\section{RESULT AND DISCUSSION}

The result of one-dimensional consolidation tests is summarized in Fig. 3. From the figure, it is observed that the vertical stresses required to compress the sample to the equal void ratio of 1.7 for remoulded, undisturbed, reconstituted with $10 \%$ cement content and reconstituted with $15 \%$ cement content are $200 \mathrm{kPa}, 500 \mathrm{kPa}, 500 \mathrm{kPa}$ and $1400 \mathrm{kPa}$, respectively. Therefore, for compression to the equal void ratio, the effective vertical stress required is minimum for remoulded sample and maximum for the reconstituted sample with $15 \%$ cement content. This is the clear indication of the improvement in the compressibility characteristics of Kalomato.

Initial void ratios of the undisturbed samples from two different tubes are found to be different but the compression index $(\mathrm{Cc})$ and swelling index $(\mathrm{Cs})$ are almost equal which are 0.992 and 0.119 respectively. It is because of the sample (UD1) has exerted higher pressure in the past i.e. higher over consolidation ratio. Whereas, the remoulding changes the compression behavior of the soil and the value of Cc decreases to 0.47 which is mainly due to the loss of soil structure after remolding (Liu et al., 2000).

When the soil is reconstituted with cement, the compression index of the soil changes with the curing time and cement content. Based on the curing time of the sample, early days sample is more compressible than the fully cured sample

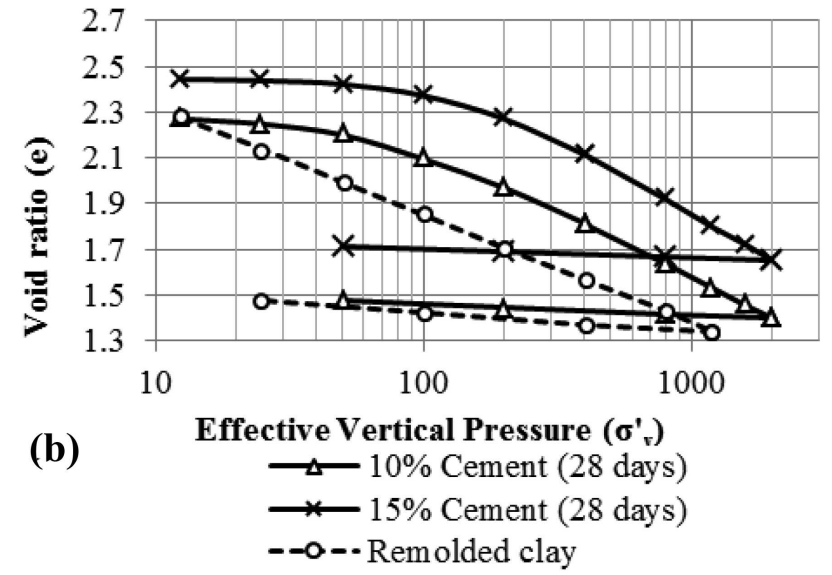
A. Different curing period,
B. Different cement content, and
C. Undisturbed sample

but there is no significant difference in swelling index. Effect of cement content is observed as the predominating factor for compression behaviour of reconstituted soil samples. Higher the cement content higher will be the compression index and primary yield strength of soil however swelling index is highest for remolded natural soil and its value is decreased with increase in cement content (Table 3). Including the undisturbed samples, it has the highest compression and swelling indices. Therefore, the compression behavior is control by the soil structure (cementation effect) of natural and reconstituted clay.

The compression index (Cc) and swelling index (Cs) of all the soil sample are presented in (Table 3). For the better visualization and understanding, the indices are plotted in Fig. 4. It is found that $\mathrm{Cc}$ increases gradually with increase in cement content of the sample on the other hand Cs decreases with the increase of cement content. There are various empirical relationships between $\mathrm{Cc}$ and $\mathrm{Cs}$ is presented by different researchers (Look and William, 1994). The interdependency between $\mathrm{Cc}$ and $\mathrm{Cs}$ of reconstituted soil is studied and found that when $\mathrm{Cc}$ increases the $\mathrm{Cs}$ will decrease significantly. Similarly, ratio of the indices $(\mathrm{Cc} / \mathrm{Cs})$ is also increased with increase in the value of $\mathrm{Cc}$.

From the laboratory investigation of Kalomato, the physical properties determined i.e. specific gravity, liquid limit, plastic limit, field density and field moisture content are within the ranges observed by the previous researchers. The compression 
Table 3: Compression and swelling index for different soil specimen

\begin{tabular}{|c|c|c|c|c|c|}
\hline \multirow{2}{*}{ Index } & \multirow{2}{*}{ Undisturbed } & \multirow{2}{*}{ Remolded } & \multicolumn{2}{|c|}{$15 \%$ Cement } & \multirow{2}{*}{$\frac{10 \% \text { Cement }}{28 \text { days }}$} \\
\hline & & & 10 days & 28 days & \\
\hline Compression Index (Cc) & 0.992 & 0.47 & 0.817 & 0.663 & 0.596 \\
\hline Swelling Index (Cs) & 0.119 & 0.081 & 0.037 & 0.037 & 0.048 \\
\hline
\end{tabular}
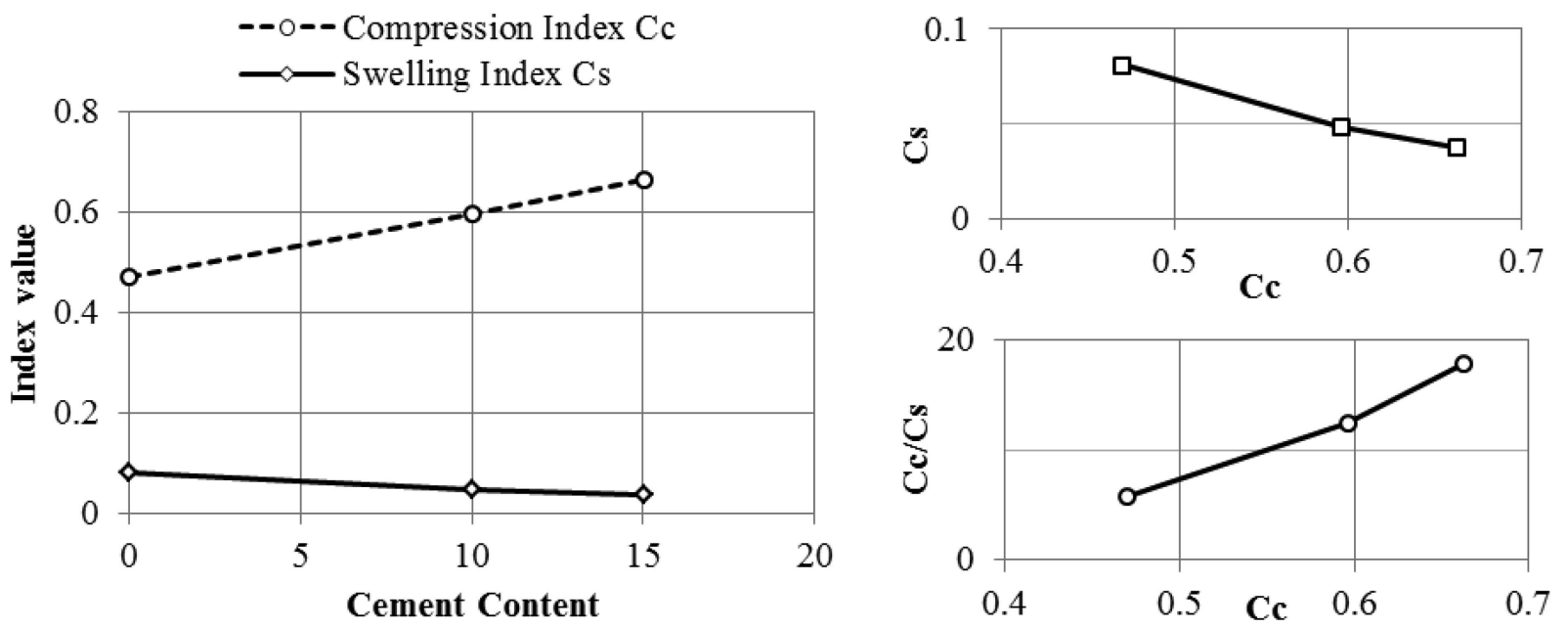

Fig. 4: Relationships between compression index, swelling index and cement content

behavior is of undisturbed samples are also found to be similar (Handali et al., 2011; Khadka, 2011). Therefore, the compression behavior of cemented Kalomato found in this study can be used as reference behavior to the soft clay present in the Kathmandu Valley.

\section{CONCLUSIONS}

The study on undisturbed, remoulded and reconstituted Kalomato revealed that the presence of structures in the clay matrix significantly affects the compression behaviour of soil. The compression index of undisturbed and remoulded soil is found as the maximum and the minimum respectively. The compression behavior of reconstituted soil indicates that the compression index tends to increase while swelling index decreases with the cement content. More importantly, the load required to compress the soil to the equal void ratio increases to almost 3 times of the undisturbed soil and 7 times of the remoulded soil when cement content increases to $15 \%$. This shows that cement is very effective to improve the compression characteristics of the Kalomato. The finding of the study can be used as reference behaviour of the soft clay exist in the Kathmandu Valley because the physical and compression properties of the study material are similar to the many samples from different locations.

\section{REFERENCES}

Bergado, D.T., Taechakumthorn, C., Lorenzo, G.A., and AbuelNaga, H.M., 2006. Stress-deformation behavior under anisotropic drained triaxial consolidation of cement-treated soft Bangkok clay. Soils and Foundations, v. 46(5), pp. 629-638.

Broms, B., 1984, Stablisation of soft clay with lime columns. Nan Yang Technological Institute, Singapore.

Dongol, G.M.S., 1987, The stratigraphic significance of vertibrate fossils from the Quaternary deposits of the Kathmandu basin, Nepal. Newsl. Stratigr., v. 18, pp. 21-29.

Handali, S., Neupane, R., Upadhyay, H.B., and Acharya, G., 2011, Engineering Characteristics of Kalomato Organic Soil From Kathmandu. Majalah Ilmiah UKRIM, v. XVI(2), pp. 33-40.

Horpibulsuk, S., Liu, M.D., Zhuang, Z., and Hong, Z., 2016, Complete Compression Curves of Reconstituted Clays. International Journal of Geomechanics, v. 16(2), pp. 1-5.

Khadka, P.B., 2011, Stress-Strain and Strength Behavior of Undrained Organic Soil in Kupondol, Kathmandu. Journal of the Institute of Engineering, v. 8(1), pp. 113-118.

Kharel, B.D., Piya, B., Singh, V.K., Shrestha, N.R., Khadka, M.S., Bhandari, R., and Muenstermann, D., 1998, Final Report, Hydrogeological Conditions and Potential Barrier Sediments in Kathmandu valley, Nepal.

Liu, M.D., Carter, J.P., Desai, C.S., and Xu, K.J., 2000, Analysis of the compression of structured soils using the disturbed state concept. International Journal for Numerical and Analytical Methods in Geomechanics, v. 24(8), pp.723-735. 
Look, B.G. and Williams, D.J., 1994, An evaluation of emperical correlations for the compression and swell indices for Queensland soil conditions. Australian Geomechanics, pp. 96-101. https://australiangeomechanics.org/wpcontent/uploads/2015/02/25_18.pdf

Nishida, Y., 1956, A Brief Note on Compression Index of Soils. Journal of Soil Mechanics and Foundations Division, vol. 83(SM3), pp. 1-14.

Piya, B., Westen, C.V., and Woldai, T., 2004, Geological database for liquefaction hazard analysis in the Kathmandu Valley, Nepal. Journal of Nepal Geological Society, v. 30, pp. 141-152.

Rendon-Herrero, O., 1980, Universal Compression Index Equation. Journal of Geotechnical Engineering Division, GT11, pp.1179-1199.

Rotta, G.V., Consoli, N.C., Prietto, P.D.M., Coop, M.R. and Graham, J., 2003, Isotropic yielding in an artificially cemented soil cured under stress. Geotechnique, v. 53(5), pp. 493-501.

Sakai, H., 2001, Stratigraphic division and sedimentary facies of the Kathmandu Basin group, Central Nepal. Jour. Nepal Geol. Soc., v. 25(Sp. Issue), pp. 19-32.
Sakai, T., Gajurel, A.P., Tabata, H., Ooi, N., Takagawa, T., Kitagawa, H., and Upreti, B.N., 2008, Revised lithostratigraphy of fluvio-lacustrine sediments comprising northern Kathmandu basin in central. Nepal. J Nepal Geol Soc, v. 37, pp. 25-44.

Skempton, A.W., 1944, Notes on the Compressibility of Clays. Quarterly Journal of Geological Society of London, v. 100, pp.119-135.

Terashi, M., 1997, Theme Lecture: Deep Mixing Method Brief State-of-Art. In: 14th ICSMFE. pp. 2475-2478.

Terzaghi, K. and Peck, R.B., 1996, Soil Mechanics in Engineering Practice. 3rd ed. John Wiley \& Sons Inc. New York. 592p.

Tiwari, B. and Ajmera, B., 2012, New Correlation Equations for Compression Index of Remolded Clays. Journal of Geotechnical and Geoenvironmental Engineering, [online] v.138(6), pp.757-762. Available at: $<$ http://ascelibrary.org/doi/10.1061/\%28ASCE\%29GT.1 943-5606.0000639>.

Xiao, H.W., 2009, Yielding and failure of cement treated soil. National Singapore University.

Yoshida, M. and Igarashi, Y.., 1984, Neogene to Quaternary lacustrine sediments in the Kathmandu Valley. Nepal. J Nepal Geol Soc, v.4(Special Issue), pp.73-100. 